DRAFT OF:

Young, H. (2016). 'Asking the 'right' questions: the constitution of school governing bodies as apolitical'. Journal of Education Policy, 31 (2), 161-177. http://dx.doi.org/10.1080/02680939.2015.1062145

\title{
Asking the 'right' questions: The constitution of school governing bodies as apolitical
}

\section{Helen Young}

Humanities and Social Sciences, UCL Institute of Education, London, UK

h.young@ioe.ac.uk

School governing bodies in England have considerable powers and responsibilities with regard to the education of pupils. This paper draws on an analysis of policy and on qualitative research in the governing bodies of four maintained schools. It explores two policy technologies through which education and the work of school governing bodies are constituted as apolitical. Firstly, it considers the move to recruit governors with (unspecified) 'skills' rather than those with a representative role who might provide diverse perspectives.

Secondly, it considers the technology of 'prescribed criticality' through which 'effective' governors are provided with the 'right' questions to ask. The paper argues that the operation of these policy technologies has significant implications for possibilities for democratic engagement in schools.

Keywords: democracy, education policy, Foucault, policy technology, school governing bodies.

\section{Introduction}

School governing bodies in England have considerable powers and responsibilities with regard to the education of pupils. This paper explores two policy technologies through which education and the work of school governing bodies are constituted as apolitical. These policy technologies might be understood as components of the operation of 'good governance as a modality of state power' (Wilkins 2014, 1). Firstly, the paper considers the move to recruit governors with (unspecified) 'skills' rather than those with a 


\section{DRAFT OF:}

Young, H. (2016). 'Asking the 'right' questions: the constitution of school governing bodies as apolitical'. Journal of Education Policy, 31 (2), 161-177. http://dx.doi.org/10.1080/02680939.2015.1062145

representative role who might provide diverse perspectives. Secondly, it considers the technology of 'prescribed criticality' through which 'effective' governors are provided with the 'right' questions to ask. The paper has emerged from a wider study of deliberative democracy, citizenship and school governing bodies which is premised on an understanding of 'politics' as ongoing contestation, diffused power and a recognition that things could be otherwise (Young 2014). The paper explores some of the ways in which the national performative system described by Fielding and Moss is constituted by discourses around school governing:

Education has been drained of overt political content and re-cast as a predominantly technical exercise, consigned to a coterie of experts, technicians and businesses whose main task is to define, improve and assess correct standards of performance. Of course, the whole neoliberal project is saturated with politics. But its status as a dominant discourse means that its values, assumptions and beliefs are rendered invisible, naturalised and neutralised, the taken-for-granted currency of everyday education. What has been lost, when most needed, is vigorous and agonistic public debate about political questions (Fielding and Moss 2012, 6-7)

The paper draws on both the analysis of policy and qualitative research in the governing bodies of four maintained schools. It begins by introducing the context of school governing bodies in England and setting out the approach to the research. It then introduces the concept of 'policy technologies' before exploring two policy technologies. These policy technologies involve emphasising 'neutral' skills and prescribing governors' 'criticality'. The paper concludes on a less optimistic note than a 


\section{DRAFT OF:}

Young, H. (2016). 'Asking the 'right' questions: the constitution of school governing bodies as apolitical'. Journal of Education Policy, 31 (2), 161-177. http://dx.doi.org/10.1080/02680939.2015.1062145

paper published in the Journal of Education Policy in 1997 in which the research hinted at:

\footnotetext{
a new culture emerging that raises future possibilities of local educational politics steering towards "double democratization": an alignment between participatory and representative democracy. (Radnor, Ball, and Vincent 1997, 221)
}

\section{Context: Education reform and school governing bodies in England}

Education reform in England has much in common with reform in many other parts of the world. However, the existence of school governing bodies in every school is more unusual. Governing bodies technically have considerable powers and responsibilities and are, therefore, significant for how education reform is enacted in England. They can be traced back at least as far as the state funded schools of the mid-nineteenth century (Deem, Brehony, and Heath 1995, 14, Sharp 1995, 1) but have changed considerably over time, particularly since the 1988 Education Reform Act (ERA) which provided 'the infrastructure for an education market and a neoliberal vision of the education system’ (Ball 2008, 80).

This section will consider broad changes which have occurred in English education policy before focusing in more detail on the current role and composition of governing bodies. Changes in education policy all have implications for the role of governors. Such changes include increasing 'school autonomy'; an emphasis on data and the commodification of knowledge; and increasing school choice. Centralised assessment targets and league tables mean that 'any new autonomy at the periphery is in 


\section{DRAFT OF:}

Young, H. (2016). 'Asking the 'right' questions: the constitution of school governing bodies as apolitical'. Journal of Education Policy, 31 (2), 161-177. http://dx.doi.org/10.1080/02680939.2015.1062145

relation to means rather than policy ends, which are set more tightly by the centre as part of a new regime of outcomes accountability' (Rizvi and Lingard 2006, 255).

Setting aims might be seen as central to playing a democratic role in education. However, despite increased 'school autonomy', governing bodies are increasingly constrained in considering the aims of education as their focus is placed on 'the extrinsic goods of effectiveness' (MacIntyre cited in Ranson 2003, 461) of the national performative system. In this system, knowledge is commodified and the resulting data provides the basis for competition and school choice. Governors become responsible for making their school marketable. It is the state, often informed by global comparisons such as those provided through PISA, that decides what data it requires and hence 'what counts as valuable knowledge' (Clarke et al. 2000, p. 9 in Ball 2007, 25). What a 'good' school means becomes associated with reaching the required standards. Questions around 'valuable' knowledge and the 'good' school, therefore, are centralised and preempted rather than resting with the pupils; school staff and management; the governors of individual schools; and/or local authorities (LAs). The implications of these developments are explored throughout this paper.

The plethora of types of school in England (including community schools, foundation and trust schools, academies and free schools) means there are many sorts of school governing bodies and an increasing number of governing bodies have responsibility for more than one school. However, the basic composition of the governing bodies of maintained schools at the time of the research was: the headteacher; staff governors elected by staff; parent governors elected by parents; LA governors 


\section{DRAFT OF:}

Young, H. (2016). 'Asking the 'right' questions: the constitution of school governing bodies as apolitical'. Journal of Education Policy, 31 (2), 161-177. http://dx.doi.org/10.1080/02680939.2015.1062145

nominated by the LA; and community governors nominated by the governing body ${ }^{1}$. This composition is premised on a concept of stakeholders which, as will be seen in the next section, is being displaced by a skills discourse. Governing bodies are made up of 7 to 20 (or even 30 ) people and are supported by a clerk. They usually hold full governing body meetings twice a term and governors join smaller committees to focus on particular aspects of school life such as curriculum or finance.

Governing bodies have a considerable number of powers and duties. At the time of the research, the role of school governing bodies included: setting the budget, appointing the headteacher and setting the school's broad direction (DCSF 2010b, DfE 2012a, Ofsted 2011). This neat summary belies the complexities of the role and a lack of clarity about governors' roles is raised in much school governance literature (Sallis 1991, 5, e.g. Balarin et al. 2008, 5, Martin and Holt 2010, 111, James 2012, 11) and was discussed by the Parliamentary Education Select Committee Inquiry into their role (Education Committee 2013). The Coalition Government, of the Conservative and Liberal Democrat parties, succeeded the New Labour Government in 2010 and said that they would simplify the role (DfE 2010, 71). This 'simplification' has also enabled a transformation and the role of governing bodies has been changing over the last five years. Their role is now described differently. At the time of the empirical research, the

${ }^{1}$ Governing bodies constituted after September 2012 have 'co-opted' rather than community governors (DfE 2012b). Depending on the type of school, some governing bodies also have foundation and or partnership governors. 


\section{DRAFT OF:}

Young, H. (2016). 'Asking the 'right' questions: the constitution of school governing bodies as apolitical'. Journal of Education Policy, 31 (2), 161-177. http://dx.doi.org/10.1080/02680939.2015.1062145

wording was the same in both the most recent New Labour and the Coalition editions of the governors' 'Guide to the Law':

The governing body must exercise its functions with a view to fulfilling a largely strategic role in the running of the school. It should establish the strategic framework by:

- setting aims and objectives for the school

- adopting policies for achieving those aims and objectives

- setting targets for achieving those aims and objectives

(DfE 2012a, 15, DCSF 2010b, 13)

The Coalition Government's 'Governors' Handbook', published after the research period, at first sight, appears similar:

In all types of schools, governing bodies should have a strong focus on three core strategic functions:

a. Ensuring clarity of vision, ethos and strategic direction;

b. Holding the headteacher to account for the educational performance of the school and its pupils; and

c. Overseeing the financial performance of the school and making sure its money is well spent

(DfE 2013, 6, 2014c, 6)

However, there are subtle but important differences. 'Setting aims' seems qualitatively different to 'ensuring clarity'. 'Setting aims' may suggest discussion by governing bodies (and hence, possibly, local communities) about what happens in 


\section{DRAFT OF:}

Young, H. (2016). 'Asking the 'right' questions: the constitution of school governing bodies as apolitical'. Journal of Education Policy, 31 (2), 161-177. http://dx.doi.org/10.1080/02680939.2015.1062145

schools. 'Ensuring', 'holding to account' and 'overseeing' may suggest governors are compliance checkers operating on behalf of national government (Young 2013). The move from 'establish the strategic framework' to 'core strategic functions' indicates the decreasing space available for alternatives to the national performative system summarised by Fielding and Moss (2012) above.

The subtle policy changes in the role of governors do not only apply to their role but also to who is valued as a governor. There has been an ongoing move to value governors with 'skills' and this was officially introduced into the regulations after the research period (DfE 2014b, 27). In March 2015, the Department for Education (DfE) announced $£ 1$ million to 'help schools across England recruit highly-skilled governors' (DfE 2015). These developments make research into the valuing of governors with 'skills' particularly timely and this is discussed under 'The discourse of 'skills"' below.

\section{Approach to research}

This paper has emerged from qualitative research with the governing bodies of four local authority (LA) maintained schools in one London borough in 2011 and 2012. Two schools, Avon and Severn, were primary and two, Mersey and Tyne, were secondary. The research involved a total of 23 meeting observations and 25 interviews. The methods of data generation and analysis were designed to explore governors' practices. The research questions for the wider research were predominantly 'how?' type questions about how concrete practices operate. These research questions were:

1. How do discourses of democracy and citizenship operate in school governing bodies? 


\section{DRAFT OF:}

Young, H. (2016). 'Asking the 'right' questions: the constitution of school governing bodies as apolitical'. Journal of Education Policy, 31 (2), 161-177. http://dx.doi.org/10.1080/02680939.2015.1062145

2. Are particular perspectives and knowledges privileged in policy and in governing bodies? If so, how?

3. What subject positions are available to governors? How are governors produced as subjects?

4. What discourses of 'good' education are drawn on in the conduct of school governing bodies?

The study schools were all within one LA as the focus was on governing bodies rather than on differences between LAs. The borough has a very mixed population with great extremes of wealth and poverty. The schools were selected largely on access grounds. I asked people who I knew to introduce me to community schools in this LA and, ultimately, I conducted research in all that agreed. My initial contact in them was with both the headteacher and the chair of governors. I recognised that headteachers who were comfortable to have their governing body meetings observed were likely to feel they had relatively positive relationships with their governors. However, I am not concerned that this was an obstacle to exploring the issues discussed in this paper.

The schools were all LA maintained schools. Avon Primary, Severn Primary and Tyne Secondary were all community schools. Mersey Secondary was a voluntary controlled school with a foundation which owns the land and nominates five of the governors. The primary schools both had about 450 students and the secondary schools both had just over 1,000 students. All four schools were mixed-sex and had more pupils than average entitled to Free School Meals (FSM is used by the government as an indicator of disadvantage). They had a significant majority of pupils from minority ethnic backgrounds, apart from Mersey Secondary where the proportion of minority ethnic pupils was closer to a half. Avon Primary placed an emphasis on 'inclusion' and 


\section{DRAFT OF:}

Young, H. (2016). 'Asking the 'right' questions: the constitution of school governing bodies as apolitical'. Journal of Education Policy, 31 (2), 161-177. http://dx.doi.org/10.1080/02680939.2015.1062145

'community' in its prospectus and the headteacher emphasised this when I met her.

Severn Primary's vision and aims (about challenge, motivation and respect) were on the first page of every school policy and appeared to drive the ethos of the school, in a way which did not seem to be the case in the other schools. The governing body meetings at Severn felt friendly and supportive to me but some of the interviewees experienced them as more intimidating. Mersey Secondary's vision emphasised citizenship, equality and 'inclusion' and the headteacher, Heidi, was very experienced. The meetings there felt very formal compared to the primary school meetings. Tyne Secondary had the following highlighted statement on its website: ' $65 \%$ of students achieving $5 \mathrm{~A}{ }^{*}-\mathrm{C}$ grades including English and Maths' and there was a very strong emphasis placed on attainment which formed a focus for many of the meetings. Their headteacher was new to headship. Tyne's full governing body meetings were very large with up to 30 people present in some meetings.

The governors were not fully reflective of their local school communities. There is a lack of national statistics about the profile of school governors. However, the national research which does exist resonates with my research in suggesting that governors are disproportionately white, middle-class and not young (Dean et al. 2007, Ellis 2003, Ranson et al. 2005). Furthermore, when it comes to those playing a more active role or forming a core group, governors can become even less representative of their local populations (e.g. Dean et al. 2007, Radnor, Ball, and Vincent 1997).

Within each school, semi-structured interviews were conducted with the headteacher and chair of governors. At least four further governors were selected for 


\section{DRAFT OF:}

Young, H. (2016). 'Asking the 'right' questions: the constitution of school governing bodies as apolitical'. Journal of Education Policy, 31 (2), 161-177. http://dx.doi.org/10.1080/02680939.2015.1062145

interview, one of each category of governor (ie: staff, parent, LA and community) ${ }^{2}$. I attempted to ensure variation in the ethnicity and gender of those interviewed. Decisions about the selection were partially determined by the role governors took in the first meeting I observed. For example, in each school, I tried to choose one who was vocal and one who was less so. In some cases, the choice of interviewee was informed by a specific discussion, for example, a group of Muslim fathers led a campaign against the sex and relationships education (SRE) taking place in some schools and this was discussed at length in a meeting where only one Muslim, a mother, was present so I was interested in her views on the framing of that particular discussion.

For each school, (non-)participant observation was conducted in up to three full governing body meetings and up to three other micro settings, including committee meetings, selected based on whether relevant dynamics and discussions were likely. The focus was on formal spaces. Nonetheless, I was aware, largely through the interviews, of the existence of informal interactions which would have been difficult to access directly. I observed both the form the discussion took and any privileging of particular voices and discourses. In the first meeting in each school, the observation was fairly open, exploring who talked and on what subject, what authority claims speakers made and the modality (or degree of commitment (Fairclough 2003, 164)) of their statements.

\footnotetext{
${ }^{2}$ The initial letter of each participant's pseudonym reflects the type of governor they were when I first met them: ' $\mathrm{H}$ ' for headteachers, ' $\mathrm{P}$ ' for parent governors, ' $\mathrm{T}$ ' for teacher governors, 'S' for support staff, 'Sp' for sponsor governors, ' $F$ ' for foundation (Mersey Secondary only), 'C' for community governor, ' $\mathrm{L}$ ' for LA governors and ' $\mathrm{A}$ ' for associate governors. The clerks were given the pseudonyms of Clark and Clara.
} 


\section{DRAFT OF:}

Young, H. (2016). 'Asking the 'right' questions: the constitution of school governing bodies as apolitical'. Journal of Education Policy, 31 (2), 161-177. http://dx.doi.org/10.1080/02680939.2015.1062145

The observations of subsequent meetings in each school were more focused on themes that emerged from the first meeting.

Agendas and minutes were also examined. Before attending meetings in each school, I reviewed the agendas and minutes for the previous year to develop an understanding of the specifics of each governing body. This provided a useful basis for the observations and interviews. Furthermore, I was able to revisit agendas and minutes to explore themes which arose from the observations and interviews.

Since the research questions aimed to explore how particular practices operated, the analysis was broadly inductive. However, it was partially guided by the research questions, the literature and my experience based expectations (Hammersley and Atkinson 2007, 165). The transcripts of all the interviews and observation notes were carefully coded and analysed using Nvivo. I used 'grounded theory methods as flexible, heuristic strategies rather than as formulaic procedures' (Charmaz 2003, 251).

Furthermore, national policy texts were analysed. The emphasis in this study was on policy that particularly relates to governing bodies but there was a recognition of the changing context of schools policy and wider public policy. Policy was analysed both as text and as discourse (Ball 2006 [1993]). Governors are not always directly aware of policy texts but are still constituted by policy discourse in complex ways. Policy texts were considered together with observations and interviews which explored aspects of governors' understanding of their role and of policy. The clerks helped to ensure that the structures and procedures of meetings largely reflected national policy. 


\section{DRAFT OF:}

Young, H. (2016). 'Asking the 'right' questions: the constitution of school governing bodies as apolitical'. Journal of Education Policy, 31 (2), 161-177. http://dx.doi.org/10.1080/02680939.2015.1062145

Headteachers played a significant part in mediating governors' understanding of education policy and, for some, training courses and local authority (LA) meetings were also significant. Ofsted inspections and rumours of the conduct and outcomes of other schools' inspections were also important for governors' understanding of their role. Since 2010, school governors had a higher profile in the media with a number of comments and speeches about them from the Secretary of State and the head of Ofsted, the national inspectorate, (e.g. Wilshaw 2013, Gove 2012a) and this has further implications for how they understand their roles. The paper discusses some of the ambivalences and ambiguities in relation to policy discourses around governors through a focus on two key policy technologies.

\section{Policy technologies}

Policy technologies or 'mechanisms of change' (Ball 2008, 101) operate to manage the reformed education system described at the beginning of the section on 'Context'. As Ball says 'Policy technologies involve the calculated deployment of techniques and artefacts to organise human forces and capabilities into functioning networks of power' (Ball 2006 [2003], 143). Policy technologies change who we are. Ball cites Foucault in suggesting that,

\footnotetext{
Neo-liberalism is made possible by a "new type of individual", an individual formed within the logic of competition - a calculating, solipsistic, instrumentally driven, "enterprise man [sic]" (Ball 2013, 132)
} 


\section{DRAFT OF:}

Young, H. (2016). 'Asking the 'right' questions: the constitution of school governing bodies as apolitical'. Journal of Education Policy, 31 (2), 161-177. http://dx.doi.org/10.1080/02680939.2015.1062145

Hence, 'policy technologies of education reform are not simply vehicles for the technical and structural change of organisations but are also mechanisms for reforming teachers ... and changing what it means to be a teacher' (Ball 2006 [2003], 145). In this paper, through analysing policy and governors' practices, I explore how two policy technologies of education reform are also changing what it means to be a governor.

Through such policy technologies, we are all implicated in the operation of neoliberalism. However, recognising the ways in which technologies operate can help us to see that, as Foucault says, 'things are not as inevitable as all that' (Ball 2006, 5). This paper suggests that a key starting point for democratic engagement is recognising the political nature of issues under discussion. This means questioning policy technologies which play a role in constituting education and governing as apolitical. Exploring these policy technologies is premised on Foucault's much quoted phrase from his debate with Chomsky:

the real political task in a society such as ours is to criticize the working of institutions which appear to be both neutral and independent; to criticize them in such a manner that the political violence which has always exercised itself obscurely through them will be unmasked, so that one can fight them (Foucault and Rabinow 1991, 6)

\section{The discourse of 'skills'}

The first policy technology discussed in this paper is that of the valuing of 'skills'. Governors' skills have been increasingly emphasised over their representative stakeholder role by both the New Labour government (e.g. DCSF 2010a) and the 


\section{DRAFT OF:}

Young, H. (2016). 'Asking the 'right' questions: the constitution of school governing bodies as apolitical'. Journal of Education Policy, 31 (2), 161-177. http://dx.doi.org/10.1080/02680939.2015.1062145

Coalition government. 'Skills' are seen as neutral and reinforce the effectiveness discourse according to which the aims of schools are clear and all schools need is effectiveness in attaining them. The Government's Schools White Paper stated that they would 'legislate in the forthcoming Education Bill so that all schools can establish smaller governing bodies with appointments primarily focused on skills' (DfE 2010, 71, para 6.30). The size was reduced in the subsequent Education Act 2011 (c.38) and the first Coalition Secretary of State for Education, Michael Gove, told Parliament:

We should encourage schools to have a tighter group of governing bodies. Governors should be chosen on the basis of their skills rather than the organisation or interest that they represent, and we can learn a lot from shining a light on the practice of the best schools. I have been really encouraged by the response of the business community, who are trying to encourage more and more people with a background in business to use some of their skills to enhance what governing bodies provide (Gove 2012b)

In a further policy move, the Coalition Government amended the regulations to require consideration of 'skills' when appointing governors.

From 1 September 2014, changes to the 2012 Constitution Regulations will require that any newly appointed governor has in the opinion of the person making the appointment "the skills required to contribute to the effective governance and success of the school". (DfE 2014b, 27) 


\section{DRAFT OF:}

Young, H. (2016). 'Asking the 'right' questions: the constitution of school governing bodies as apolitical'. Journal of Education Policy, 31 (2), 161-177. http://dx.doi.org/10.1080/02680939.2015.1062145

The increasing policy focus on governors having 'skills' has important effects, as suggested by Gove's statement above. 'Skills' is often used in opposition to 'representation' so the valuing of governors with skills operates to simultaneously devalue representative governors. 'Skills' tend to be associated, in policy discourse and by governors in the study schools, with business and a business rationality. Furthermore, as mentioned, the language of skills reinforces a conception of governing as an apolitical technical process. The actual skills required do not need to be specified in order for the policy technology to have these effects. In fact the lack of clarity aids its operation as there are limited specific skills that anyone might disagree with.

Policy discourse has tended to be around a binary between skilled and representative stakeholder governors. The Parliamentary Education Select Committee has an important role in scrutinising the work of the Government. The Committee held a major inquiry into the role of school governing bodies and, in its initial call for evidence, it asked for submissions to comment on 'the structure and membership of governing bodies, including the balance between representation and skills' (Education Committee 2013, 5). However, it did not make any recommendations in relation to this 'balance'. Its report acknowledged the debate but made no contribution to it:

Evidence to our inquiry showed mixed opinions on the appropriate balance in a school governing body between individuals with specific skills, and representatives of stakeholder groups. Overall, there was agreement with the DfE's view that the stakeholder model does not preclude skills, but, conversely, several witnesses felt that individuals recruited for specific skills may lack important local or community knowledge. (Education Committee 2013, 7) 


\section{DRAFT OF:}

Young, H. (2016). 'Asking the 'right' questions: the constitution of school governing bodies as apolitical'. Journal of Education Policy, 31 (2), 161-177. http://dx.doi.org/10.1080/02680939.2015.1062145

In national policy debates, there are different understandings of what skills governors should or might have. The following discussion of skills for pro bono work shows the lack of clarity about the skills required on governing bodies. Some skills are more tangible and, therefore, easier to talk about than others. The Confederation of British Industry included the following in its submission to the Education Select Committee Inquiry:

We recommend that government suggest the types of skills that school governing bodies should seek to recruit, such as strong financial skills or human resources expertise (CBI 2013, 3)

Such tangible skills might be consistent with a depoliticised 'state volunteer' (Deem, Brehony, and Heath 1995) discourse. However, James et al and the National Governors Association (NGA) explicitly warn against governors drawing on such skills to do pro bono work which would suggest governors should play an operational role in schools:

Governors with functional/operational skills, such as financial or human resource management, are often welcomed onto governing bodies because those skills may be of value in ensuring the effective operation of the school... Recruiting governors because of their functional skills may suggest that they have operational responsibility, which is not part of the governors' remit (James et al. 2010, 17)

there has been a trend to recruit lawyers to governing bodies, but a number of lawyers have found that once on the governing body, they are not being asked to bring their analytical skills to governance, but are being asked to provide the 


\section{DRAFT OF:}

Young, H. (2016). 'Asking the 'right' questions: the constitution of school governing bodies as apolitical'. Journal of Education Policy, 31 (2), 161-177. http://dx.doi.org/10.1080/02680939.2015.1062145

school with "pro bono" legal advice. Given the time which has to be taken to explain to both governing bodies and school leaders what is strategic and what is operational, it is not helpful to promote the misunderstanding that you are strengthening your business functions by bringing people with business skills onto the governing body; governing bodies need to ensure that the school staff are capable of undertaking their roles... the key skills required include such things as influencing skills, negotiation and data analysis (NGA 2013b, 4)

In the interviews and observations, there were numerous examples of governors doing pro bono legal, financial and human resources work, for example:

I am a free source of expert HR advice to them in the personnel committee meetings. And we have got people who are financial experts who provide that sort of consultancy work on finance. We have got people who work in, you know various roles, including IT, that allow them to give expert advice on a consultancy basis unpaid (Leonard, LA governor at Tyne Secondary)

we have got [Leah, an LA governor] who is a lawyer. And so when we came [to this site], the community house [was let under] a 15 year lease and we thought we couldn't get out of it. [Leah] read through the contract and said you can get out of it. Um so that was brilliant... [Pir, a parent governor] will do translation for us (Hazel, Headteacher at Severn Primary)

Apart from the parent governor, Pir's, Somali-English translation skills, these 'functional/operational skills' (James et al. 2010, 17) were associated with the finance and personnel committees which were the higher status committees: 


\section{DRAFT OF:}

Young, H. (2016). 'Asking the 'right' questions: the constitution of school governing bodies as apolitical'. Journal of Education Policy, 31 (2), 161-177. http://dx.doi.org/10.1080/02680939.2015.1062145

I think when they are looking to involve parents who haven't got an obvious um skill set that corresponds with the finance or personnel, then the obvious choice is to try and involve them in the community and curriculum committees because it is more immediate to their interests as parents (Leonard, Tyne)

Unlike the experiences of parenthood, 'skills' tend to be presented as valuable, neutral and context free even though they are often associated with business.

In constituting education and governing as apolitical, the point of this policy technology is not to pin down specific skills but to leave them open. This is exemplified by the statutory guidance on the new 2014 regulations. It has a section on 'The skills governing bodies need' which is quoted below to show the openness of the definition which even includes 'personal attributes'. The lack of clear definition makes the 'skills' difficult to disagree with:

The skills governing bodies need

16. The Regulations, as amended, create an explicit requirement that all appointed governors have the skills required to contribute to effective governance and the success of the school. The specific skills that governing bodies need to meet their particular challenges will vary. It is therefore for governing bodies and other appointing persons to determine in their own opinion, having regard to this guidance, what these skills are and be satisfied that the governors they appoint have them.

They may interpret the word skills to include personal attributes, qualities and capabilities, such as the ability and willingness to learn and develop new skills. 17. Experience has shown that all governors need a strong commitment to the role and to improving outcomes for children, the inquisitiveness to question and analyse, and the willingness to learn. They need good inter-personal skills, 


\section{DRAFT OF:}

Young, H. (2016). 'Asking the 'right' questions: the constitution of school governing bodies as apolitical'. Journal of Education Policy, 31 (2), 161-177. http://dx.doi.org/10.1080/02680939.2015.1062145

appropriate levels of literacy in English (unless a governing body is prepared to make special arrangements), and sufficient numeracy skills to understand basic data. Foundation governors need the skills to understand the ethos of the school and its implications for the way it is governed.

18. Experience also shows that effective governing bodies seek to secure or develop within their membership as a whole expertise and experience in analysing performance data, in budgeting and driving financial efficiency, and in performance management and employment issues, including grievances. They seek to recruit and/or develop governors with the skills to work constructively in committees, chair meetings and to lead the governing body.

19. It is governing bodies' responsibility to identify and secure the induction and other ongoing training and development governors need...

(my emphasis, DfE 2014a, 7)

The emphasis on business as a source of 'skills' has been reinforced by the Inspiring Governors Alliance which was formed as 'the result of discussions between the Department for Education, the National Governors' Association, NCOGS [National Co-ordinators of Governor Services], CBI [Confederation of British Industry], SGOSS [SGOSS - Governors for Schools, previously known as SGOSS (School Governors One-Stop-Shop)] and the Education and Employers Taskforce' (Inspiring Governors Alliance 2014).

The business influence in the study schools, was not as crude as suggesting the school should become an academy or buy more services from private companies. In fact, business governors spoke against both of these things in meetings which I observed. Their influence was cultural and more subtle. Connor equated business with positive qualities which had no logical connection to business a few times in each 


\section{DRAFT OF:}

Young, H. (2016). 'Asking the 'right' questions: the constitution of school governing bodies as apolitical'. Journal of Education Policy, 31 (2), 161-177. http://dx.doi.org/10.1080/02680939.2015.1062145

meeting. These positive qualities ranged from punctuality to clear referencing in policies. The phone system at Tyne Secondary was not good and he said you would not expect that in a business (my notes, Tyne Full, May 2012). Hayley, the head, talked about staff who were leaving and welcomed Cathy's offer of the template which they used for exit interviews in a bank (my notes, Tyne Full, Jul 2012). Larry, who worked in another bank, referred to having skills in planning which he drew on as a link governor and first presented as generic skills:

I work closely with a teacher one-to-one. So this is in IT, sort of the technology side so you get partnered up and you work closely with that teacher to provide, to present, to put together plans for instance, for one year, three year plan in terms of how they are going to develop the teaching in that area. So that's again, again, you know, because putting together plans and putting together, you know, where you want to be some way ahead, three years' time, is something I am relatively comfortable with so, genuinely feel that I can provide a lot of sort of input and support there through the governing body and then through this sort of one-to-one type sessions (Larry, LA Governor at Severn Primary)

However, when I asked him specifically about the difference between business plans and school plans, he suggested there were differences after all, saying, 'I think they're coming more from these subjective intangible. I am coming more from a very tangible, very black and white side of things' (Larry). The idea that banking practices are black and white can mask the values inherent within banking. Furthermore, Larry's initial understanding of his planning skills as neutral provides an example of the way in which "neoliberal rationality ...functions as a "politics of truth"' (Lemke 2002, 55) and 


\section{DRAFT OF:}

Young, H. (2016). 'Asking the 'right' questions: the constitution of school governing bodies as apolitical'. Journal of Education Policy, 31 (2), 161-177. http://dx.doi.org/10.1080/02680939.2015.1062145

is difficult to see beyond. Some, mostly staff, governors identified problematic differences between the cultures of business and education in our interviews but these differences did not tend to be raised in meetings.

To summarise the first policy technology, there has been an increasing push towards the recruitment of governors with 'skills' in policy discourse and regulation. Despite, and partly because of, the lack of clarity about what 'skills' might mean, the discourse of 'neutral' skills has significant effects. Firstly, 'skills' tends to be used in policy discourse to devalue 'representation' through the construction of a skills/representation binary. Secondly, 'skills' tend to be associated with business and a business rationality. Thirdly, the language of skills suggests that education is an apolitical technical process which merely requires skills to ensure effectiveness. The following section considers a second policy technology which complements this 'neutral' skills discourse in constituting school governing as apolitical and concerned solely with a technical process.

\section{Prescribed criticality: 'Asking the right questions' ${ }^{3}$}

Questioning is central to the role of governors and may appear to be a way in which challenges to national policies and school practices might emerge. However, questioning as a practice is conceived narrowly in policy to the extent that lists of questions are produced by governor support organisations and national policy makers

\footnotetext{
${ }^{3}$ This is the heading of a section in the 'Governors' Handbook' (DfE 2014c, 8-9).
} 


\title{
DRAFT OF:
}

Young, H. (2016). 'Asking the 'right' questions: the constitution of school governing bodies as apolitical'. Journal of Education Policy, 31 (2), 161-177. http://dx.doi.org/10.1080/02680939.2015.1062145

for use by governors. This form of questioning is extremely far removed from Foucault's conceptualisation of critique. Foucault's 'critique' might provide challenges to the national performative system:

\begin{abstract}
A critique is not a matter of saying that things are not right as they are. It is a matter of pointing out on what assumptions, what kinds of familiar, unchallenged, unconsidered modes of thought, the practices that we accept rest... to see that what is accepted as self-evident will no longer be accepted as such. (Foucault (1988a: 154) cited in Olssen, Codd, and O'Neill 2004, 40)
\end{abstract}

The limited form of questioning in which governors engage might sometimes appear similar to this form of critique but it is, arguably, a largely technical process. Governors might be described as performing 'prescribed criticality'. This is a technology through which the 'right' questions to ask are provided for governors through training, policy documents and their headteacher's instruction. Their 'critical' questioning can be seen as a performance or fabrication. Ball is referring here to the inspection of teachers:

What is produced is a spectacle, or game-playing, or cynical compliance, or what we might see as an "enacted fantasy" (Butler, 1990), which is there simply to be seen and judged - a fabrication (Ball 2006 [2003], 149)

Governors provide another layer to this. Teachers and headteachers perform for governors who perform, in turn, for Ofsted, the national inspectorate. Governors 


\section{DRAFT OF:}

Young, H. (2016). 'Asking the 'right' questions: the constitution of school governing bodies as apolitical'. Journal of Education Policy, 31 (2), 161-177. http://dx.doi.org/10.1080/02680939.2015.1062145

specifically ask questions which are minuted by the clerk in order to demonstrate criticality to Ofsted.

Governor training sessions and literature also provide lists of appropriate questions that governors can ask to ensure that their school is complying with national policy. Despite hearing about others, the only training session I observed during the research period was at Avon Primary. In this, the concept of 'challenging questions' was discussed and a long list of 'challenging questions' was provided in the hand-out ${ }^{4}$ possibly implying that governors would be unable to develop 'challenging questions' on their own. These questions focus on governors taking a significant role in asking questions about attainment data and in compliance checking. This takes place in a national context which Ozga suggests "can be described as the most "advanced" in Europe in terms of data production and use' $(2009,149)$.

Ofsted provided additional guidance to governors in 'School Governance: Learning from the best' (Ofsted 2011) which provides a number of examples of questions asked by 'effective' governing bodies. This report was a specific agenda item at Avon Primary (my notes, Avon Full GB, 3 October 2011). At Mersey Secondary, Frederick, the chair, referred to the 'Key characteristics of effective governing bodies' in this document as 'The 10 commandments' (my notes, Mersey Finance Committee, July 2011). Heidi, the head, described the document as the 'new regulations'. I did not

\footnotetext{
${ }^{4}$ For an example from a non-London borough, see http://great-governance.org.uk/governancetools/ask-the-right-questions/.
} 


\section{DRAFT OF:}

Young, H. (2016). 'Asking the 'right' questions: the constitution of school governing bodies as apolitical'. Journal of Education Policy, 31 (2), 161-177. http://dx.doi.org/10.1080/02680939.2015.1062145

hear it mentioned at Tyne Secondary or Severn Primary but the study period there was 12 months after the report had been published.

Avon Primary's 2010 Ofsted report, judged the school to be 'Good' but the governing body was only judged to be 'Satisfactory'. Extending the governors' evaluation systems was given as one of the key areas which the school needed to improve. Hence, each subsequent meeting at Avon seemed to involve performances of governing which were minuted to impress Ofsted. Following are examples from one meeting of references to writing minutes in such a way as to impress Ofsted. Firstly, the governors were focussed on ensuring that all visits to the school were minuted (my notes, Avon Full GB, Nov 11). Secondly, with regard to the uniform consultation, Heidi, headteacher at Mersey Secondary and a Community Governor at Avon Primary, said 'it's a great example of governors leading. Clara [the clerk], write it down! Very good' (my notes, Avon Full GB, Nov 11). Thirdly, in a more light-hearted tone, Heidi responded to the comments of a new local authority governor:

Latif - it is important if our resources are constrained that we focus our energies.

We could lower our expectations

Heidi - don't write "low expectations" down!

(my notes, Avon Full GB, Nov 11)

Clark, the clerk at Tyne Secondary and Severn Primary, was unhappy with this Ofsted expectation that 'challenge' appear in the minutes, saying that it 'runs counter to how one does minutes' (Clark). 


\section{DRAFT OF:}

Young, H. (2016). 'Asking the 'right' questions: the constitution of school governing bodies as apolitical'. Journal of Education Policy, 31 (2), 161-177. http://dx.doi.org/10.1080/02680939.2015.1062145

Meetings in the four study schools consisted largely of information giving and questioning was limited, beyond basic information gathering. However, 'good' questioning was both encouraged and minuted in all four reinforcing this performance of 'good' questioning. Since the time of the research there has been an even greater push in national policy for governors to ask the 'right' questions rather than coming up with their own. A 2012 Ofsted report, below, resonates with what Hannah said in 2011:

So I kind of feel a responsibility to try to make it work and try and get them to ask the right questions of me. Rather than being them asking the challenging questions. Heh. Do you know what I mean? (Hannah, headteacher at Avon Primary)

Ofsted's (2012) 'Getting to Good: How headteachers achieve success' encouraged headteachers to 'train' their governors in asking questions and referred to weak governing bodies which 'had not been sufficiently well trained to know the questions they should be asking' (16).

The 2013 Education Select Committee Inquiry suggested that governors could not be trusted to develop their own questions and needed even more specific guidance, saying:

Many witnesses, including Mark Taylor of Cambridge Education, Islington, believed there were "dangers in letting governors make up the questions themselves" and this guidance would be best developed nationally." 


\title{
DRAFT OF:
}

Young, H. (2016). 'Asking the 'right' questions: the constitution of school governing bodies as apolitical'. Journal of Education Policy, 31 (2), 161-177. http://dx.doi.org/10.1080/02680939.2015.1062145

\author{
The generic questions in the new Governors' Handbook are helpful, but will not in \\ themselves provide sufficient assistance to governing bodies in interrogating \\ complex data. We look forward to DfE publishing further questions \\ (my emphasis, Education Committee 2013, 25)
}

The NGA subsequently published a further series of questions for its members (NGA 2013a). This external provision of questions is consistent with a neo-liberal rationality of effectiveness but is far removed from a recognition of the political nature of governing and of education. It is even further removed from Foucault's conception of 'critique'.

In the course of the wider study, I carried out a detailed analysis looking for challenges to narrow conceptions of 'good' education within the governing body meetings which I observed (Young 2014). I was particularly interested to consider how challenges might occur to the narrow attainment focus of the national performative system. 'Challenge discourse' was one of my codes for looking at interviews and observations. The code description was: 'Challenge neoliberal discourse; Challenge discourse of derision about schools; Challenge prevailing discourse in school'. I was surprised how little appeared under this code in all four schools. The very small number of challenges which did occur came from the opposite perspective to what I was looking for. There were challenges from those with a business perspective who wanted schools to adopt more business practices (as described in the previous section) and from those with experiences of private and more privileged schools who wanted more support for the 'more able'. The headteachers could have been seen as providing challenges to new 


\section{DRAFT OF:}

Young, H. (2016). 'Asking the 'right' questions: the constitution of school governing bodies as apolitical'. Journal of Education Policy, 31 (2), 161-177. http://dx.doi.org/10.1080/02680939.2015.1062145

national policies but their negative comments about policies could also be seen as grumbles rather than as actual challenges. In meetings, there did not seem to be any challenges to the national performative system from non-staff governors. Despite not finding the significant challenges which I was looking for, what the analysis does hint at is that it is the small micro-practices that constantly reinforce the dominant discourse. In the case of the challenges which I saw, these included the reinforcement of the valuing of business practices and of the division of pupils into a hierarchy of 'ability' based on their variable attainment at particular points in time. An optimist might suggest that drawing on such micro-practices could also be used to challenge the dominant discourse of the national performative system and to 'transform commonsense' (Apple 2013, 214). There is the possibility that governors' increased awareness of how the policy technologies described in this article operate might enable them to disrupt them through small acts of challenge.

In relation to the second policy technology of 'prescribed criticality' described in this section, I want to suggest that being told how to be 'critical' reduces the possibilities of governors being critical in a broader sense; in challenging the current constitution of the education system. This technology of the provision of 'critical' questions acts as a kind of immunisation against governors developing meta-critical questions. It is another example of their busy-ness and passivity (Young 2014). Governors are encouraged to keep busy asking prescribed questions but are passive in considering what conception of 'good' education lies behind these questions. 


\section{DRAFT OF:}

Young, H. (2016). 'Asking the 'right' questions: the constitution of school governing bodies as apolitical'. Journal of Education Policy, 31 (2), 161-177. http://dx.doi.org/10.1080/02680939.2015.1062145

\section{Reflections}

The concept of 'policy technologies' (Ball 2006 [2003], 145) has provided a fruitful way to explore the practices of school governing bodies. This paper has explored two policy technologies which contribute to the constitution of governing bodies as apolitical and concerned solely with education as a technical matter rather than a public good with implications for all of society.

Firstly, there is an increasing push towards recruiting and valuing governors with 'skills' on governing bodies. What these skills actually are is unclear. Skills are often understood in opposition to representation and the language of skills reinforces the idea of education as a technical matter which can be governed through 'neutral' skills assumed to come from business.

Secondly, through the technology of 'prescribed criticality', governors are provided with the 'right' questions to ask. These questions are premised on a singular narrow conception of 'good' education, as consistent with the national performative system, and provide for the performance of criticality whilst mitigating against a wider practice of criticality. Hence, governors are very busy but at the same time are passive in the face of recognising and engaging in the political nature of governing schools.

The increasing constitution of education and of governing as apolitical, through multiple policy technologies including those described in this paper, has significant implications: some voices are not heard; there is little creative dialogue which might lead to the emergence and collective exploration of alternative ideas that individuals did 


\section{DRAFT OF:}

Young, H. (2016). 'Asking the 'right' questions: the constitution of school governing bodies as apolitical'. Journal of Education Policy, 31 (2), 161-177. http://dx.doi.org/10.1080/02680939.2015.1062145

not come to the meeting with; and the productive power of national policy discourse and of actors such as headteachers is masked. All this precludes an understanding of politics as ongoing contestation, a ubiquitous play of power and a recognition that things could be otherwise.

\section{Acknowlegements}

The original research for the article formed part of my $\mathrm{PhD}$ which was funded by an ESRC Studentship. Additional support was provided through a BELMAS Bursary in 2014. Professor Carol Vincent and Professor Stephen Ball have provided extremely helpful support and advice. I am also very grateful to two anonymous reviewers who provided constructive comments on an earlier draft of this paper.

\section{Notes on contributor}

Helen Young completed her $\mathrm{PhD}$ at the Institute of Education, London in 2014. This qualitative study explored the practices of school governing bodies drawing on understandings of deliberative democracy and citizenship as sensitising concepts.

\section{References}

Education Act 2011 (c.38). London: HMSO.

Apple, M W. 2013. "Between traditions: Stephen Ball and the critical sociology of education." London Review of Education no. 11 (3):206-217. doi: 10.1080/14748460.2013.840981.

Balarin, M, S Brammer, C James, and M McCormack. 2008. Governing our Schools: The School Governance Study. London: Business in the Community.

Ball, S J. 2006. "Introduction: The problem of policy." In Education policy and social class: The selected works of Stephen J. Ball, edited by S J Ball, ix, 290. London: Routledge.

Ball, S J. 2006 [1993]. "What is Policy? Texts, trajectories and toolboxes." In Education policy and social class: The selected works of Stephen J. Ball, edited by S J Ball, 43-53. London: Routledge. 
DRAFT OF:

Young, H. (2016). 'Asking the 'right' questions: the constitution of school governing bodies as apolitical'. Journal of Education Policy, 31 (2), 161-177. http://dx.doi.org/10.1080/02680939.2015.1062145

Ball, S J. 2006 [2003]. "The teacher's soul and the terrors of performativity." In Education policy and social class: The selected works of Stephen J. Ball, edited by S J Ball, 143-156. London: Routledge.

Ball, S J. 2007. Education plc: Understanding private sector participation in public sector education. London: Routledge.

Ball, S J. 2008. The education debate, Policy and politics in the twenty-first century. Bristol: Policy Press.

Ball, S J. 2013. Foucault, power, and education. Abingdon: Routledge.

CBI. 2013. Written evidence submitted by Confederation of British Industry (CBI) to the Education Select Committee Inquiry on 'The role of School Governing Bodies'. London: Parliament.

Charmaz, K. 2003. "Grounded theory: Objectivist and constructivist methods." In Strategies of qualitative inquiry, edited by N K Denzin and Y S Lincoln, 249291. London: Sage.

DCSF. 2010a. The 21st Century School: Implications and Challenges for Governing Bodies, A report from the Ministerial Working Group on School Governance. London: DCSF.

DCSF. 2010b. A Guide to the Law for School Governors. 13th ed. London: Department for Children, Schools and Families.

Dean, C, A Dyson, F Gallannaugh, A Howes, and C Raffo. 2007. Schools, governors and disadvantage. York: Joseph Rowntree Foundation.

Deem, R, K Brehony, and S Heath. 1995. Active Citizenship and the Governing of Schools. Milton Keynes: Open University Press.

DfE. 2010. The Importance of Teaching: The Schools White Paper 2010. Norwich: TSO.

DfE. 2012a. The Governors' Guide to the Law. London: HMSO.

DfE. 2012b. Statutory Guidance on the School Governance (Constitution) (England) Regulations 2012. London: DfE.

DfE. 2013. Governors' Handbook: For governors in maintained schools, academies and free schools. London: HMSO. 


\section{DRAFT OF:}

Young, H. (2016). 'Asking the 'right' questions: the constitution of school governing bodies as apolitical'. Journal of Education Policy, 31 (2), 161-177. http://dx.doi.org/10.1080/02680939.2015.1062145

DfE. 2014a. The constitution of governing bodies of maintained schools: Statutory guidance for governing bodies of maintained schools and local authorities in England, May 2014. London: DfE.

DfE. 2014b. Governors' Handbook: For governors in maintained schools, academies and free schools. HMSO.

DfE. 2014c. Governors' Handbook: For governors in maintained schools, academies and free schools. HMSO.

DfE. $£ 1$ million to help schools recruit high-calibre governors 2015. Available from https://www.gov.uk/government/news/1-million-to-help-schools-recruit-highcalibre-governors.

Education Committee. 2013. The Role of School Governing Bodies, Second Report of Session 2013-14, Volume I: Report, together with formal minutes. London: HMSO.

Ellis, A. 2003. Barriers to participation for under-represented groups in school governance. London: DfES Research Report.

Fairclough, N. 2003. Analysing Discourse: Textual analysis for social research. London: Routledge.

Fielding, M, and P Moss. 2012. Radical Democratic Education. In American Sociological Association 2012 Annual Meeting. Denver, Colorado.

Foucault, M, and P Rabinow. 1991. The Foucault reader. Edited by Paul Rabinow. London: Penguin.

Gove, M. FASNA's first twenty years - pioneers of excellence: Speech on 5 July.

Department for Education 2012a. Available from http://www.education.gov.uk/inthenews/speeches/a00211347/fasnaspeech.

Gove, M. House of Commons, Oral Evidence taken before the Education Committee on 'The responsibilities of the Secretary of State for Education' on 31 January 2012 (HC 1786i). www.parliament.uk 2012b. Available from http://www.publications.parliament.uk/pa/cm201012/cmselect/cmeduc/1786/120 13101.htm.

Hammersley, M, and P Atkinson. 2007. Ethnography: Principles in practice. 3rd ed. London: Routledge. 


\section{DRAFT OF:}

Young, H. (2016). 'Asking the 'right' questions: the constitution of school governing bodies as apolitical'. Journal of Education Policy, 31 (2), 161-177. http://dx.doi.org/10.1080/02680939.2015.1062145

Inspiring Governors Alliance. About the Alliance 2014. Available from http://www.inspiringgovernors.org/about-the-alliance/.

James, C. 2012. "Trends in the Governance and Governing of Schools in England." Local Government Studies (ahead-of-print):1-17.

James, C, S Brammer, M Connolly, M Fertig, J James, and J Jones. 2010. The 'hidden givers': A study of school governing bodies in England. Reading: CfBT.

Lemke, T. 2002. "Foucault, Governmentality and Critique." Rethinking Marxism: A Journal of Economics, Culture and Society no. 14 (3):49-64.

Martin, J, and A Holt. 2010. Joined-up governance: Making sense of the role of the school governor. 3rd ed. Norwich: Adamson Publishing.

NGA. 2013a. Knowing your School: Questions for governing bodies to ask. In $A$ series of briefing notes for school governors from the National Governors' Association produced in association with partners. Birmingham: National Governors' Association.

NGA. Written evidence submitted by the National Governors Association to the Education Select Committee Inquiry on 'The role of School Governing Bodies'. Parliament 2013b. Available from http://data.parliament.uk/writtenevidence/WrittenEvidence.svc/EvidencePdf/174 L.

Ofsted. 2011. School governance: Learning from the best. London: Ofsted.

Ofsted. 2012. Getting to Good: How headteachers achieve success. London: Ofsted.

Olssen, M, J Codd, and A-M O'Neill. 2004. Education policy: Globalization, citizenship and democracy. London: Sage.

Ozga, J. 2009. "Governing education through data in England: From regulation to self-evaluation." Journal of Education Policy no. 24 (2):149-162.

Radnor, H, S Ball, and C Vincent. 1997. "Whither democratic accountability in education? An investigation into headteachers' perspectives on accountability in the 1990s with reference to their relationships with their LEAs and governors." Research Papers in Education no. 12 (2):205-222.

Ranson, S. 2003. "Public accountability in the age of neo-liberal governance." Journal of Education Policy no. 18 (5):459-480. doi: 10.1080/0268093032000124848. 


\section{DRAFT OF:}

Young, H. (2016). 'Asking the 'right' questions: the constitution of school governing bodies as apolitical'. Journal of Education Policy, 31 (2), 161-177. http://dx.doi.org/10.1080/02680939.2015.1062145

Ranson, S, M Arnott, P McKeown, J Martin, and P Smith. 2005. "The participation of volunteer citizens in school governance." Educational Review no. 57 (3):357371. doi: 10.1080/00131910500149457.

Rizvi, F, and B Lingard. 2006. "Globalization and the Changing Nature of the OECD's Educational Work." In Education, globalization, and social change, edited by Hugh Lauder, Philip Brown, Jo-Anne Dillabough and A. H Halsey, 247-260. Oxford: Oxford UP.

Sallis, J. 1991. School governors: Your questions answered. London: Hodder.

Sharp, P. 1995. School governing bodies in the English education system: An historical perspective, Educational administration and history monographs. Leeds: University of Leeds School of Education.

Wilkins, A. 2014. "Professionalizing school governance: the disciplinary effects of school autonomy and inspection on the changing role of school governors." Journal of Education Policy:1-19. doi: 10.1080/02680939.2014.941414.

Wilshaw, M. Creating a step change in school accountability: Equipping parents and governors with the information needed to assess school performance - Speech at Policy Exchange, 27 February 2013 2013. Available from http://www.policyexchange.org.uk/modevents/item/sir-michael-wilshawcreating-a-step-change-in-school-accountability-equipping-parents-andgovernors-with-the-information-needed-to-assess-school-performance.

Young, H. The New Governors' Handbook: What has happened to the role of governors in 'setting aims'? 2013. Available from http://saseproject.com/2013/06/22/the-governors-handbook-what-has-happenedto-the-role-of-governors-in-setting-aims/.

Young, H. 2014. Ambiguous Citizenship: Democratic practices and school governing bodies Humanities and Social Science, Institute of Education, London. 